\title{
Determination of Sustainable Financial Index: BUKU 4 Period 2016 - 2019
}

\author{
Teresia Angelia Kusumahadi ${ }^{1}$, Adji Pratikto ${ }^{2}$ and \\ Ansgarius Davin Ruli ${ }^{3}$ \\ ${ }^{123}$ Faculty of Economics and Business, \\ Atma Jaya Catholic University of Indonesia
}

adji.pratikto@atmajaya.ac.id

\begin{abstract}
Sustainable finance is one of the instruments that can be used to achieve sustainable development goals. Practices of sustainable finance are regulated in the Financial Services Authority Regulation No. 51 / POJK.03 / 2017 ("POJK 51"), where one of the requirements in its implementation is to publish a Sustainability Report annually. However, before being obliged to release a Sustainability Report, banks, particularly BUKU 4, had published the report. Seeing that the Sustainability Report has been prepared before reporting requirements, these banks are running a sustainable business. To measure the level of sustainability of a bank, we build a Sustainable Financial Index. The Sustainable Financial Index is compiled based on 42 indicators built on sustainable finance's eight principles. Using Bank Mandiri, $B C A, B N I, B R I$, and Bank CIMB as the observed bank, the results show that the Sustainable Financial Index for each bank has increased from year to year. The increment indicates that the practice of sustainable finance is running well in BUKU 4. Besides, each bank has different characteristics; thus, the principles that stand out in implementing sustainable finance differ from one bank to another. However, the index has several limitations, so that further index development is required.

Keywords: BUKU 4, Sustainable Financial Index, POJK 51, Sustainability Report
\end{abstract}

JEL : G21, G28, Q01, Q56

DOI : 10.24002/kinerja.v25i1.4358

Received : 11/22/2021 Reviewed: 02/11/2021 Final Version: 03/09/2021 


\section{INTRODUCTION}

With the United Nations' resolution on the Sustainable Development Goals (UN Resolution 70/1), all United Nations (UN) members have the same commitment to accomplish these development goals by 2030. The Sustainable Development Goals consists of 17 goals and 169 targets, completing the Millennium Development Goals, and resolving what has not been achieved.

Indonesia as a member of the UN, has also implemented the Sustainable Development Goals ("SDGs") in the National Medium-Term Development Plan (2020-2024), where all objectives and indicators have been accommodated in 7 development agendas. The seven development agendas are:

a. Strengthening economic resilience for quality and equitable growth

b. Developing areas to reduce inequality

c. Increasing the quality and competitiveness of human resources

d. Forming a mental revolution and cultural development

e. Maintaining infrastructure to support economic development and essential services

f. Building the environment, increasing disaster resilience and climate change

g. Enhancing the stability of the law, defense and security, and transformation of public services

The Ministry of National Development Planning/Bappenas, as the coordinator of development in Indonesia, has invited all elements of the government and parliament, philanthropy and business, community organizations and media, academics, and experts to implement the SDGs agenda a success.

As an authorized institution to regulate the financial services industry, The Financial Services Authority issues regulations that support the implementation of the SDGs agenda, particularly in the financial sector. They issued Roadmap for Sustainable Finance in Indonesia (Otoritas Jasa Keuangan, 2014), followed by the Financial Services Authority Regulation No. 51 / POJK.03 / 2017 ("POJK 51"). In this regulation, sustainable finance is defined as comprehensive support from the financial services sector to create sustainable economic growth by aligning economic, social, and environmental interests. To achieve this, the Financial Services Authority ("OJK") requires financial services institutions to prepare a Sustainable Financial Action Plan ("RAKB") and prepare a Sustainability Report annually.

The RAKB itself is a written document that describes the plan for business activities and work programs of financial services institutions, both in the short term (1 year) and the long term (5 years). The RAKB includes a strategy for work plans and programs that have been determined by financial services institutions. The RAKB must be submitted to OJK at the same time as the submission of the bank's 
business plan and must be submitted to stakeholders after obtaining approval from OJK.

Meanwhile, a Sustainability Report is a report that contains economic, financial, social, and environmental performance carried out by financial service institutions in running a sustainable business. This Sustainability Report must be submitted to the public no later than April of the following year and comes into force for financial services institutions with the following conditions:

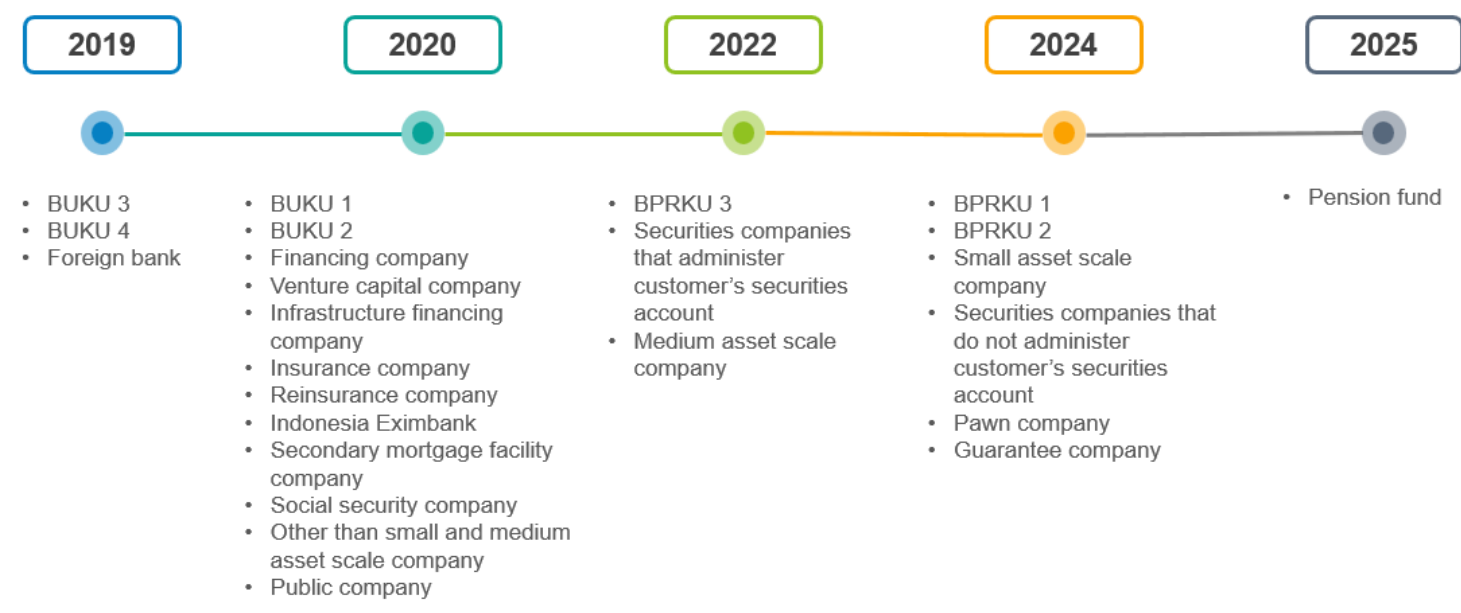

Figure 1. Sustainability Report Submission Timeline

With the enactment of this reporting obligation, each year, financial service institutions will release a Sustainability Report, starting with BUKU 3, BUKU 4, and foreign banks for the first reporting period of 2019, up to pension fund institutions for the first reporting period in 2025. Sustainability reports can be reported as an inseparable part of the Annual Report or reported separately from the Annual Report.

However, before being obliged to release a Sustainability Report, banks, particularly BUKU 4, had published the report. Several BUKU 4 have published their Sustainability Report for the period, shown in Table 1. Meanwhile, the authors did not find the Sustainability Report's publication on the two banks' websites, which are also included in BUKU 4, namely PT Bank Pan Indonesia Tbk. and PT Bank Danamon Indonesia Tbk.

Table 1. List of Availability of Sustainability Report

\begin{tabular}{lc}
\hline Bank Name & Availability of Sustainability Report \\
\hline PT Bank Rakyat Indonesia (Persero) Tbk (“BRI”) & $2016-2019$ \\
PT Bank Negara Indonesia (Persero) Tbk (“BNI”) & $2009-2019$ \\
PT Bank Mandiri (Persero) Tbk (“Bank Mandiri”) & $2013-2019$ \\
PT Bank Central Asia Tbk (“BCA”) & $2015-2019$ \\
PT Bank CIMB Niaga Tbk (“Bank CIMB”) & $2012-2019$ \\
\hline
\end{tabular}

Source: Bank's public website 
Since the Sustainability Report was prepared before reporting obligations, these banks have certainly been running a sustainable business, concerned with economic and financial aspects and social and environmental aspects. Based on this, to measure these banks' sustainability, the author will conduct a study by compiling an index, hereinafter referred to as the Sustainable Financial Index. The Sustainable Financial Index is compiled based on indicators built on the principles used from sustainable finance itself. This index is expected to fill the gap in Indonesia's currently no index on sustainable finance.

\section{LITERATURE REVIEW}

Sustainable finance is a measure of an institution's ability to maintain its activities (Bisogno, Cuadrado-Ballesteros and García-Sánchez, 2017; Piot-Lepetit and Nzongang, 2014; Pati, 2008). Sustainable finance is related to these institutions' activities in managing inputs and producing the community's outputs. In the financial services and banking industry, where the industry manages funds owned by the community, sustainable finance is an absolute must. Therefore, the OJK, as the institution that supervises the financial services industry and banking, must be able to carry out its functions properly so that the public funds can be used to encourage economic activity.

As previously explained, POJK 51 (Otoritas Jasa Keuangan, 2017) defines sustainable finance as comprehensive support from the financial services sector to create sustainable economic growth by aligning economic, social, and environmental interests. The principles used in sustainable finance are practically explained in the Technical Guidelines for Banks Regarding POJK 51 (Otoritas Jasa Keuangan, 2018). These principles are as follows:

1. The principle of responsible investment is an investment principle in which decisions are taken to consider economic, social, and environmental factors and governance. This principle is needed so that banks can better manage risks. Therefore, in the end, they can generate long-term sustainable benefits, including economic benefits, social welfare, environmental quality, and governance enforcement. Banks can apply this principle in stages according to their financial condition, structure, and complexity. The practical measure is the allocation of bank assets and liabilities that considers the impact of economic, social, environmental, and governance risks.

2. The principle of sustainable business strategy and practices is a principle in which every bank's decision must be made based on sustainable business strategies and practices. The strategy and sustainable business practices include the vision, mission, organizational structure, strategic plans, standard operating procedures, work programs to determine risk factors in raising or distributing funds, and integrating economic, social, and environmental aspects. 
3. The principles of social and environmental risk management. In carrying out its business, banks must apply the prudential banking principle to measure social and environmental risks from those activities by identifying, measuring, mitigating, and monitoring the risks. The risks that may arise from bank activities include negative social and environmental impacts of the financed project.

4. The principle of good governance is the enforcement of a bank's governance implemented through business management and operations. Good governance principles include transparency, accountability, responsibility, independence, professionalism, equality, and fairness.

5. The principle of informative communication. Every bank must provide a report (RAKB and Sustainability Report) that is informative, easy to understand, and accountable. The report must be submitted to all stakeholders through effective and accessible communication media.

6. The principle of inclusion must be made by the bank to ensure the availability of products and/or services. The bank must ensure these products can be reached by all people, even for people with no access. With this access, it is hoped that economic progress, social welfare, and the environment can be achieved.

7. The principle of priority sector development. Each bank must consider the priority sectors that have been set by the government. By taking into account the priority sectors, banks support sustainable development goals, including addressing climate change.

8. Principle of coordination and collaboration. To improve economic, social, and environmental welfare, banks need to coordinate and collaborate with all stakeholders to align strategies/policies, business opportunities, and product innovation. Banks need to participate actively in forums/activities/cooperation related to sustainable finance.

\section{METHODOLOGY}

The Sustainable Financial Index is prepared to assess whether banks, particularly BUKU 4, have implemented sustainable finance practices. The index will first be compiled for the five banks listed in Table 1 using the 2016 to 2019 period. Before producing the index, the authors first collect the indicators used as the basis for The Sustainable Financial Index assessment. The indicators referred to are indicators based on the principles of sustainable finance described above. The indicators consist of 42 indicators, as shown in Table 2. 
Table 2. Sustainable Financial Index Indicator

\begin{tabular}{|c|c|c|c|}
\hline No. & Principle & Indicator & Remarks \\
\hline 1 & $\begin{array}{l}\text { The principle of } \\
\text { responsible investment }\end{array}$ & Capital Adequacy Ratio & $\begin{array}{l}\text { The capital adequacy ratio is } \\
\text { based on the bank's risk profile }\end{array}$ \\
\hline 2 & $\begin{array}{l}\text { The principle of } \\
\text { responsible investment }\end{array}$ & $\begin{array}{l}\text { Non-Performing Earning } \\
\text { Assets and Non-Earning } \\
\text { Assets to } \\
\text { Total Earning Assets and } \\
\text { Non-Earning Assets }\end{array}$ & $\begin{array}{l}\text { Non-performing earning assets } \\
\text { and non-earning assets to } \\
\text { total earning assets and non- } \\
\text { earning assets of the bank }\end{array}$ \\
\hline 3 & $\begin{array}{l}\text { The principle of } \\
\text { responsible investment }\end{array}$ & $\begin{array}{l}\text { Non-Performing Earning } \\
\text { Assets to Total Earning } \\
\text { Assets }\end{array}$ & $\begin{array}{l}\text { Non-performing earning assets } \\
\text { to total earning assets of the } \\
\text { bank }\end{array}$ \\
\hline 4 & $\begin{array}{l}\text { The principle of } \\
\text { responsible investment }\end{array}$ & $\begin{array}{l}\text { Allowance Provision on } \\
\text { Earning Assets to Total } \\
\text { Earning Assets }\end{array}$ & $\begin{array}{l}\text { Allowance provision on earning } \\
\text { assets to total earning assets of } \\
\text { the bank }\end{array}$ \\
\hline 5 & $\begin{array}{l}\text { The principle of } \\
\text { responsible investment }\end{array}$ & NPL Gross & The bank's NPL Gross \\
\hline 6 & $\begin{array}{l}\text { The principle of } \\
\text { responsible investment }\end{array}$ & Return on Asset (ROA) & $\begin{array}{l}\text { The bank's Return on Asset } \\
\text { (ROA) }\end{array}$ \\
\hline 7 & $\begin{array}{l}\text { The principle of } \\
\text { responsible investment }\end{array}$ & Return on Equity (ROE) & $\begin{array}{l}\text { The bank's Return on Equity } \\
\text { (ROE) }\end{array}$ \\
\hline 8 & $\begin{array}{l}\text { The principle of } \\
\text { responsible investment }\end{array}$ & Net Interest Margin (NIM) & $\begin{array}{l}\text { Net Interest Margin (NIM) is the } \\
\text { ratio of net interest income to } \\
\text { the earning asset of the bank }\end{array}$ \\
\hline 9 & $\begin{array}{l}\text { The principle of } \\
\text { responsible investment }\end{array}$ & $\begin{array}{l}\text { Operating Expenses to } \\
\text { Operating Revenues } \\
\text { (BOPO) }\end{array}$ & $\begin{array}{l}\text { The efficiency ratio is measured } \\
\text { by comparing operating } \\
\text { expenses to the operating } \\
\text { income of the bank }\end{array}$ \\
\hline 10 & $\begin{array}{l}\text { The principle of } \\
\text { responsible investment }\end{array}$ & $\begin{array}{l}\text { Loan to Deposit Ratio } \\
\text { (LDR) }\end{array}$ & $\begin{array}{l}\text { Loan to Deposit (LDR) is a } \\
\text { comparison between the total } \\
\text { loan to the total deposit of the } \\
\text { bank }\end{array}$ \\
\hline 11 & $\begin{array}{l}\text { The principle of } \\
\text { responsible investment }\end{array}$ & $\begin{array}{l}\text { Liquidity Coverage Ratio } \\
\text { (LCR) }\end{array}$ & $\begin{array}{l}\text { It is a comparison between } \\
\text { High-Quality Liquid Asset and } \\
\text { total net cash outflow for the } \\
\text { next } 30 \text { days in a stressful } \\
\text { scenario }\end{array}$ \\
\hline
\end{tabular}




\begin{tabular}{|c|c|c|c|}
\hline No. & Principle & Indicator & Remarks \\
\hline 12 & $\begin{array}{l}\text { The principle of } \\
\text { responsible investment }\end{array}$ & $\begin{array}{l}\text { Sustainable business } \\
\text { activity categories } \\
\text { financing }\end{array}$ & $\begin{array}{l}\text { Amount of credit lent to the } \\
\text { sustainable business activity } \\
\text { categories }{ }^{1} \text { compared to the } \\
\text { total credit of the bank }\end{array}$ \\
\hline 13 & $\begin{array}{l}\text { The principle of } \\
\text { responsible investment }\end{array}$ & $\begin{array}{l}\text { NPL of sustainable } \\
\text { business activity } \\
\text { categories }\end{array}$ & $\begin{array}{l}\text { NPL of sustainable business } \\
\text { activity categories }\end{array}$ \\
\hline 14 & $\begin{array}{l}\text { The principle of } \\
\text { responsible investment }\end{array}$ & $\begin{array}{l}\text { The number of products } \\
\text { and/or services that meet } \\
\text { the criteria for sustainable } \\
\text { business activity } \\
\text { categories }\end{array}$ & $\begin{array}{l}\text { The number of products and/or } \\
\text { services that meet the } \\
\text { requirements for sustainable } \\
\text { business activity categories }\end{array}$ \\
\hline 15 & $\begin{array}{l}\text { The principle of } \\
\text { responsible investment }\end{array}$ & $\begin{array}{l}\text { Percentage of raised } \\
\text { funds from products } \\
\text { and/or services that meet } \\
\text { the criteria of sustainable } \\
\text { business activity } \\
\text { categories }\end{array}$ & $\begin{array}{l}\text { Allocation of raised funds from } \\
\text { products and/or services that } \\
\text { meet the requirements of } \\
\text { sustainable business activity } \\
\text { categories to the total third-party } \\
\text { fund }\end{array}$ \\
\hline 16 & $\begin{array}{l}\text { The principle of } \\
\text { sustainable business } \\
\text { strategy and practices }\end{array}$ & $\begin{array}{l}\text { Change in electricity } \\
\text { usage }\end{array}$ & $\begin{array}{l}\text { Changes in bank's electricity } \\
\text { usage compared to the previous } \\
\text { period }\end{array}$ \\
\hline 17 & $\begin{array}{l}\text { The principle of } \\
\text { sustainable business } \\
\text { strategy and practices }\end{array}$ & Change in water usage & $\begin{array}{l}\text { Changes in bank's water usage } \\
\text { compared to the previous period }\end{array}$ \\
\hline 18 & $\begin{array}{l}\text { The principle of } \\
\text { sustainable business } \\
\text { strategy and practices }\end{array}$ & Change in paper usage & $\begin{array}{l}\text { Changes in bank's paper usage } \\
\text { compared to the previous period }\end{array}$ \\
\hline 19 & $\begin{array}{l}\text { The principle of } \\
\text { sustainable business } \\
\text { strategy and practices }\end{array}$ & Change in fuel usage & $\begin{array}{l}\text { Changes in bank's fuel usage } \\
\text { compared to the previous period }\end{array}$ \\
\hline 20 & $\begin{array}{l}\text { The principle of } \\
\text { sustainable business } \\
\text { strategy and practices }\end{array}$ & $\begin{array}{l}\text { Percentage of CSR } \\
\text { budget allocation in the } \\
\text { environmental sector }\end{array}$ & $\begin{array}{l}\text { The portion of allocation of funds } \\
\text { in the environmental sector to } \\
\text { the total fund for CSR activities }\end{array}$ \\
\hline 21 & $\begin{array}{l}\text { The principle of } \\
\text { sustainable business } \\
\text { strategy and practices }\end{array}$ & $\begin{array}{l}\text { The percentage of fund } \\
\text { allocation related to } \\
\text { improving environmental } \\
\text { quality and supporting the } \\
\text { bank's core business }\end{array}$ & $\begin{array}{l}\text { The ratio of fund allocation } \\
\text { related to improving } \\
\text { environmental quality and } \\
\text { supporting the bank's core } \\
\text { business and the funds issued } \\
\text { by the bank for CSR activities }\end{array}$ \\
\hline
\end{tabular}

\footnotetext{
${ }^{1}$ Sustainable business activity categories prioritize efficiency and effectiveness in using natural resources; prevent or limit or reduce or repair environmental damage, pollution, waste, ecosystem damage, and social injustice or inequality; and / or provide solutions for communities facing the impacts of climate change.
} 


\begin{tabular}{|c|c|c|c|}
\hline No. & Principle & Indicator & Remarks \\
\hline 22 & $\begin{array}{l}\text { The principle of } \\
\text { sustainable business } \\
\text { strategy and practices }\end{array}$ & $\begin{array}{l}\text { Human resource } \\
\text { development budget } \\
\text { allocation related to the } \\
\text { implementation of } \\
\text { sustainable finance }\end{array}$ & $\begin{array}{l}\text { Budget allocation for human } \\
\text { resource development related to } \\
\text { the implementation of } \\
\text { sustainable finance to total } \\
\text { budget allocations for a human } \\
\text { resource as a whole }\end{array}$ \\
\hline 23 & $\begin{array}{l}\text { The principles of social } \\
\text { and environmental risk } \\
\text { management }\end{array}$ & $\begin{array}{l}\text { A description of the } \\
\text { identification, } \\
\text { measurement, mitigation, } \\
\text { and monitoring carried } \\
\text { out by the bank for } \\
\text { sustainable business }\end{array}$ & $\begin{array}{l}\text { The availability of complete } \\
\text { explanation regarding the } \\
\text { identification, measurement, } \\
\text { mitigation, and monitoring } \\
\text { carried out by banks on } \\
\text { sustainable business }\end{array}$ \\
\hline 24 & $\begin{array}{l}\text { The principles of social } \\
\text { and environmental risk } \\
\text { management }\end{array}$ & $\begin{array}{l}\text { Availability of an } \\
\text { environmental impact } \\
\text { analysis (AMDAL) for the } \\
\text { potential debtor }\end{array}$ & $\begin{array}{l}\text { The availability of mandatory } \\
\text { environmental impact analysis } \\
\text { (AMDAL) for the potential debtor }\end{array}$ \\
\hline 25 & $\begin{array}{l}\text { The principles of social } \\
\text { and environmental risk } \\
\text { management }\end{array}$ & $\begin{array}{l}\text { Number of the program in } \\
\text { RAKB }\end{array}$ & $\begin{array}{l}\text { The number of bank's programs } \\
\text { listed in the RAKB }\end{array}$ \\
\hline 26 & $\begin{array}{l}\text { The principles of social } \\
\text { and environmental risk } \\
\text { management }\end{array}$ & $\begin{array}{l}\text { Percentage of realization } \\
\text { of a sustainable finance } \\
\text { action plan }\end{array}$ & $\begin{array}{l}\text { Percentage of realization of a } \\
\text { sustainable finance action plan }\end{array}$ \\
\hline 27 & $\begin{array}{l}\text { The principle of good } \\
\text { governance }\end{array}$ & $\begin{array}{l}\text { The availability of } \\
\text { standard operating } \\
\text { procedures regarding } \\
\text { sustainable finance }\end{array}$ & $\begin{array}{l}\text { The availability of standard } \\
\text { operating procedures regarding } \\
\text { sustainable finance }\end{array}$ \\
\hline 28 & $\begin{array}{l}\text { The principle of good } \\
\text { governance }\end{array}$ & $\begin{array}{l}\text { The availability of a } \\
\text { particular function or } \\
\text { working unit for the } \\
\text { implementation of } \\
\text { sustainable finance }\end{array}$ & $\begin{array}{l}\text { The availability of a particular } \\
\text { function or working unit for the } \\
\text { implementation of sustainable } \\
\text { finance }\end{array}$ \\
\hline 29 & $\begin{array}{l}\text { The principle of good } \\
\text { governance }\end{array}$ & $\begin{array}{l}\text { Percentage of workers } \\
\text { based on gender }\end{array}$ & $\begin{array}{l}\text { The percentage of male workers } \\
\text { to the total workers in the bank }\end{array}$ \\
\hline 30 & $\begin{array}{l}\text { The principle of good } \\
\text { governance }\end{array}$ & $\begin{array}{l}\text { Percentage of workers } \\
\text { based on position and } \\
\text { gender }\end{array}$ & $\begin{array}{l}\text { The difference in the percentage } \\
\text { of male and female workers with } \\
\text { a minimum middle management } \\
\text { position to the total workers in } \\
\text { the bank }\end{array}$ \\
\hline 31 & $\begin{array}{l}\text { The principle of good } \\
\text { governance }\end{array}$ & $\begin{array}{l}\text { Percentage of workers } \\
\text { with disabilities }\end{array}$ & $\begin{array}{l}\text { Percentage of workers with } \\
\text { disabilities to the total number of } \\
\text { workers in the bank }\end{array}$ \\
\hline 32 & The principle of good & $\begin{array}{l}\text { Percentage of permanent } \\
\text { employee remuneration }\end{array}$ & $\begin{array}{l}\text { Percentage of remuneration for } \\
\text { permanent employees at the }\end{array}$ \\
\hline
\end{tabular}

${ }^{2}$ The percentage of realization can be calculated if the bank includes indicators of success in the RAKB 


\begin{tabular}{|c|c|c|c|}
\hline No. & Principle & Indicator & Remarks \\
\hline & governance & $\begin{array}{l}\text { against regional minimum } \\
\text { wages }\end{array}$ & $\begin{array}{l}\text { lowest level against regional } \\
\text { minimum wages }\end{array}$ \\
\hline 33 & $\begin{array}{l}\text { The principle of } \\
\text { informative } \\
\text { communication }\end{array}$ & $\begin{array}{l}\text { The availability of RAKB } \\
\text { and Sustainability Report }\end{array}$ & $\begin{array}{l}\text { The availability of RAKB }{ }^{3} \text { and } \\
\text { Sustainability Report based on } \\
\text { POJK } 51 \text { requirement }\end{array}$ \\
\hline 34 & $\begin{array}{l}\text { The principle of } \\
\text { informative } \\
\text { communication }\end{array}$ & $\begin{array}{l}\text { The timeliness of RAKB } \\
\text { dan Sustainability Report } \\
\text { submission }\end{array}$ & $\begin{array}{l}\text { The timeliness of RAKB dan } \\
\text { Sustainability Report submission } \\
\text { based on POJK } 51 \text { requirement }\end{array}$ \\
\hline 35 & The principle of inclusion & $\begin{array}{l}\text { Percentage of branch } \\
\text { offices by region }\end{array}$ & $\begin{array}{l}\text { Differences in branch offices }{ }^{4} \text { in } \\
\text { Java and non-Java }\end{array}$ \\
\hline 36 & The principle of inclusion & $\begin{array}{l}\text { The number of digital } \\
\text { banking services }\end{array}$ & $\begin{array}{l}\text { The number of digital banking } \\
\text { services owned by banks, } \\
\text { including mobile banking, } \\
\text { internet banking, branchless } \\
\text { banking, and others }\end{array}$ \\
\hline 37 & The principle of inclusion & $\begin{array}{l}\text { Percentage of customer's } \\
\text { complaints that have } \\
\text { been handled }\end{array}$ & $\begin{array}{l}\text { Percentage of public complaints } \\
\text { handled by the banks }\end{array}$ \\
\hline 38 & $\begin{array}{l}\text { The principle of priority } \\
\text { sector development }\end{array}$ & $\begin{array}{l}\text { The number of priority } \\
\text { sectors for sustainable } \\
\text { finance }\end{array}$ & $\begin{array}{l}\text { The number of priority sectors } \\
\text { for sustainable finance } \\
\text { determined by the banks }\end{array}$ \\
\hline 39 & $\begin{array}{l}\text { The principle of priority } \\
\text { sector development }\end{array}$ & $\begin{array}{l}\text { Percentage of target } \\
\text { achievement in } \\
\text { sustainable finance } \\
\text { priority sectors }\end{array}$ & $\begin{array}{l}\text { Percentage of target } \\
\text { achievement in sustainable } \\
\text { finance priority sectors }\end{array}$ \\
\hline 40 & $\begin{array}{l}\text { The principle of } \\
\text { coordination and } \\
\text { collaboration }\end{array}$ & $\begin{array}{l}\text { The number of } \\
\text { competency development } \\
\text { related to sustainable } \\
\text { finance }\end{array}$ & $\begin{array}{l}\text { The number of competency } \\
\text { developments provided by } \\
\text { banks to employees, including } \\
\text { training, workshops, and FGDs, } \\
\text { related to sustainable finance }\end{array}$ \\
\hline 41 & $\begin{array}{l}\text { The principle of } \\
\text { coordination and } \\
\text { collaboration }\end{array}$ & $\begin{array}{l}\text { Socialization to the } \\
\text { community regarding the } \\
\text { environment }\end{array}$ & $\begin{array}{l}\text { The number of socializations } \\
\text { provided by banks to the public } \\
\text { regarding the environment }\end{array}$ \\
\hline 42 & $\begin{array}{l}\text { The principle of } \\
\text { coordination and } \\
\text { collaboration }\end{array}$ & $\begin{array}{l}\text { Percentage of employees } \\
\text { attending sustainable } \\
\text { finance training }\end{array}$ & $\begin{array}{l}\text { Percentage of employees who } \\
\text { attended sustainable finance } \\
\text { training compared to the total } \\
\text { bank employees }\end{array}$ \\
\hline
\end{tabular}

\subsection{Sustainable Financial Index Construction Process}

${ }^{3}$ The availability of RAKB from 2018 until 2019

${ }^{4}$ Branch offices that are included in the calculation are main branch offices and sub-branch offices 
The index construction process is adapted from the method used by Lee and Huang (Lee and Huang, 2007). The indicators used have different units, so in establishing the Sustainable Financial Index, the authors first standardize the indicators to aim that existing indicators can be compared. Standardization is used using the standard deviation method, with the following formula:

$$
x_{i t}^{*}=\frac{x_{i t}-\bar{x}}{\sigma}
$$

where $x_{i}^{*}$ is the standardized value of indicator $i$ in ${ }^{t}$ period, $x_{i}$ is the value of indicator $i$ in ${ }^{t}$ period, $\bar{x}$ is the mean of indicator $x_{i}$ in the observation period (2016 2019). A positive standardization value indicates that the indicator's value is higher than the indicator's average value for four years. On the other hand, a negative standardization value suggests that the indicator is lower than the indicator's average value for four years.

To make these indicators easier to calculate, the authors made standardized indicators in a value range of 0 to 1 , with the following formula:

$$
y_{i t}=\frac{x_{i t}^{*}-a}{e-a}
$$

where $y_{i t}$ is an indicator value ranging from 0 to $1, a$ is the lowest value of $x_{i t}^{*}$, dan ${ }^{e}$ is the highest value of $x_{i t}^{*}$.

However, not all indicators whose value is close to 1 indicate sustainable finance. The existence of sustainable finance is characterized by a value close to 0 on NPL indicators, electricity usage changes, paper usage changes, water usage changes, and several other indicators. Based on this, the authors make adjustments to these indicators, with the following formula:

$$
y_{i t}^{*}=\left(1-y_{i t}\right)
$$

With this adjustment, the indicator value close to 1 indicates the existence of sustainable finance. After obtaining the indicator value, the authors weighted it. The same weights are given for the eight principles used so that each principle's weight is $12.5 \%$. The weighting can be seen in the below table.

Table 3. Weight of Indicators

\begin{tabular}{lccc}
\hline The Principle of Sustainable Finance & $\begin{array}{c}\text { Weight per } \\
\text { principle }\end{array}$ & $\begin{array}{c}\text { Number of } \\
\text { indicators }\end{array}$ & $\begin{array}{c}\text { Weight per } \\
\text { indicators }\end{array}$ \\
\hline The principle of responsible investment & 0.125 & 15 & 0.0083 \\
$\begin{array}{l}\text { The principle of sustainable business } \\
\text { strategy and practices }\end{array}$ & 0.125 & 7 & 0.0179 \\
$\begin{array}{l}\text { The principles of social and environmental } \\
\text { risk management }\end{array}$ & 0.125 & 4 & 0.0313 \\
\hline
\end{tabular}




\begin{tabular}{lccc}
\hline The principle of good governance & 0.125 & 6 & 0.0208 \\
The principle of informative communication & 0.125 & 2 & 0.0625 \\
The principle of inclusion & 0.125 & 3 & 0.0417 \\
$\begin{array}{l}\text { The principle of priority sector development } \\
\begin{array}{l}\text { The principle of coordination and } \\
\text { collaboration }\end{array}\end{array}$ & 0.125 & 2 & 0.0625 \\
\hline Total weight & 0.125 & 3 & 0.0417 \\
\hline
\end{tabular}

Source: Author's calculation

\section{RESULT AND DISCUSSION}

Based on the index construction process carried out above, Sustainable Financial Index is generated for each bank, as shown in the table below.

Table 4. Sustainable Financial Index 2016 - 2019

\begin{tabular}{cccccc}
\hline Index & Mandiri & BCA & BNI & BRI & CIMB \\
\hline $\mathbf{2 0 1 6}$ & 0.2045 & 0.2345 & 0.0879 & 0.1889 & 0.0831 \\
$\mathbf{2 0 1 7}$ & 0.2770 & 0.2221 & 0.2302 & 0.1527 & 0.0964 \\
$\mathbf{2 0 1 8}$ & 0.4518 & 0.4576 & 0.4508 & 0.3478 & 0.2878 \\
$\mathbf{2 0 1 9}$ & 0.7261 & 0.6848 & 0.6055 & 0.4168 & 0.5754
\end{tabular}

Source: Author's calculation

From the table above, it can be seen that overall, for each bank, Sustainable Financial Index has experienced a significant increase from year to year. For Bank Mandiri, Sustainable Financial Index experienced the largest increase by 0.5216 points from 2016 to 2019, followed by an increase in BNI by 0.5176 points; Bank CIMB by 0.4924 points; BCA 0.4502 points; and an increase in BRI by 0.228 points from 2016 to 2019 .

The increase in Sustainable Financial Index can be caused by several things, including the increased awareness of banks to implement sustainable finance in their business processes and improved knowledge of sustainable finance. The increase in Sustainable Financial Index can be related to the implementation of POJK 51 regulations that oblige banks to implement sustainable financial programs, of which BUKU 4 is mandatory starting in 2019.

Based on the results obtained, as shown in Table 4, Bank Mandiri is the bank with the largest Sustainable Financial Index in 2019, at 0.7261 ; followed by $\mathrm{BCA}$ at 0.6848; BNI 0.6055; Bank CIMB at 0.5754; and BRI at 0.4168. The explanation of each bank's principles contributing to the Sustainable Financial Index can be seen in the table below. 
Table 5. Sustainable Financial Index Composition Based on Principles - Bank Mandiri

\begin{tabular}{lcccc}
\hline Bank Mandiri & $\mathbf{2 0 1 6}$ & $\mathbf{2 0 1 7}$ & $\mathbf{2 0 1 8}$ & $\mathbf{2 0 1 9}$ \\
\hline $\begin{array}{l}\text { The principle of responsible } \\
\text { investment }\end{array}$ & 0.0291 & 0.0522 & 0.0480 & 0.0754 \\
$\begin{array}{l}\text { The principle of sustainable } \\
\text { business strategy and practices }\end{array}$ & 0.0400 & 0.0436 & 0.0545 & 0.0768 \\
$\begin{array}{l}\text { The principles of social and } \\
\text { environmental risk management }\end{array}$ & 0.0313 & 0.0313 & 0.0625 & 0.1250 \\
$\begin{array}{l}\text { The principle of good governance } \\
\begin{array}{l}\text { The principle of informative } \\
\text { communication }\end{array}\end{array}$ & 0.0417 & 0.0532 & 0.0689 & 0.0798 \\
$\begin{array}{l}\text { The principle of inclusion } \\
\begin{array}{l}\text { The principle of priority sector } \\
\text { development }\end{array}\end{array}$ & 0.0625 & 0.0625 & 0.1250 & 0.1250 \\
$\begin{array}{l}\text { The principle of coordination and } \\
\text { collaboration }\end{array}$ & 0.0000 & 0.0224 & 0.0513 & 0.0833 \\
\hline Sustainable Financial Index & $\mathbf{0 . 2 0 4 5}$ & $\mathbf{0 . 2 7 7 0}$ & $\mathbf{0 . 4 5 1 8}$ & $\mathbf{0 . 7 2 6 1}$ \\
\hline
\end{tabular}

Source: Author's calculation

Table 5 shows that Bank Mandiri has started to apply sustainable finance principles from 2016, and the index has increased from year to year, especially in 2019. It can be seen that there is no zero value in each principle in the year 2019. The principle of inclusion that was not previously found in the 2016's Sustainability Report has continued to increase in subsequent years. The increase in the principle of inclusion from year to year indicates that the bank has made efforts to ensure the availability of products and/or services and ensure that all people can reach these products and/or services. The increase in the principle of inclusion can be seen from the increase in branch offices outside Java from year to year so that people outside Java can enjoy the bank's products and/or services. Besides, the number of banking services has also increased, leading to the expansion of banking access in the community. The number of complaints handled by the bank has also increased, which indicates that the bank has a high commitment to serve every community without exception.

The principle of coordination and collaboration at Bank Mandiri has also increased from 2016 to 2019, indicating an increase in coordination and collaboration between Bank Mandiri and stakeholders, especially Bank Mandiri employees, which can be seen from the increasing number of competency development related to sustainable finance. However, one of the indicators used in the study, namely the percentage of employees who participated in competency 
development regarding sustainable finance, was not presented in the Sustainability Report, so the authors did not know the number of employees who had received competency development. Also, the absence of information regarding the amount of socialization carried out to the community related to the environment has resulted in the low value of this principle compared to other principles.

Apart from the above principles, the principles of responsible investment, sustainable business strategy and practices, and good governance principles have also increased from year to year. The increase in these principles indicates that banks are increasingly considering economic, social, and environmental factors in conducting their business, including the increase in the percentage of credit extended by banks for sustainable enterprises; reduction of electricity, water, paper, and fuel usage in 2019 compared to previous years; as well as the existence of standard operating procedures regarding sustainable finance and the presence of a particular unit that handles the implementation of sustainable finance at Bank Mandiri.

The principles of social and environmental risk management, the principles of informative communication, and the principle of priority sector development are the principles that have been fully implemented by Bank Mandiri. The implementation can be seen from the maximum value in 2019 based on the index construction indicators. This high value indicates that Bank Mandiri has implemented the precautionary principle in its business practices, including identifying, measuring, mitigating, and monitoring sustainable business. Besides, there is also an obligation to analyze the environmental impacts of prospective debtors. Bank Mandiri has also fulfilled the principles of informative communication marked by the availability of a Sustainability Report and a RAKB submitted to stakeholders at a predetermined time.

Table 6. Sustainable Financial Index Composition Based on Principles - BCA

\begin{tabular}{lcccc}
\hline BCA & $\mathbf{2 0 1 6}$ & $\mathbf{2 0 1 7}$ & $\mathbf{2 0 1 8}$ & $\mathbf{2 0 1 9}$ \\
\hline $\begin{array}{l}\text { The principle of responsible } \\
\text { investment }\end{array}$ & 0.0500 & 0.0441 & 0.0631 & 0.0707 \\
$\begin{array}{l}\text { The principle of sustainable } \\
\text { business strategy and practices }\end{array}$ & 0.0179 & 0.0403 & 0.0406 & 0.0237 \\
$\begin{array}{l}\text { The principles of social and } \\
\text { environmental risk management }\end{array}$ & 0.0000 & 0.0000 & 0.0625 & 0.0938 \\
$\begin{array}{l}\text { The principle of good governance } \\
\begin{array}{l}\text { The principle of informative } \\
\text { communication }\end{array}\end{array}$ & 0.0208 & 0.0295 & 0.0481 & 0.0890 \\
$\begin{array}{l}\text { The principle of inclusion } \\
\begin{array}{l}\text { The principle of priority sector } \\
\text { development }\end{array}\end{array}$ & 0.0625 & 0.0625 & 0.1250 & 0.1250 \\
\hline
\end{tabular}




\begin{tabular}{lcccc}
\hline BCA & $\mathbf{2 0 1 6}$ & $\mathbf{2 0 1 7}$ & $\mathbf{2 0 1 8}$ & $\mathbf{2 0 1 9}$ \\
\hline $\begin{array}{l}\text { The principle of coordination and } \\
\text { collaboration }\end{array}$ & 0.0000 & 0.0108 & 0.0650 & 0.1250 \\
\hline Sustainable Financial Index & $\mathbf{0 . 2 3 4 5}$ & $\mathbf{0 . 2 2 2 1}$ & $\mathbf{0 . 4 5 7 6}$ & $\mathbf{0 . 6 8 4 8}$ \\
\hline
\end{tabular}

Source: Author's calculation

Table 6 describes the composition of the Sustainable Financial Index in BCA based on sustainable finance principles. Just like Bank Mandiri, the principles of sustainable finance have started to be applied at BCA starting in 2016, although we can see that not all of the principles were fulfilled in that year. Significant improvements occurred in social and environmental risk management principles, the principle of priority sector development, and coordination and collaboration principles. The principle of social and environmental risk management, which initially had zero value in 2016, has increased from 2018 to 2019. There has been an increase in this principle due to implementing the precautionary principle in its business practices. Banks have also required prospective debtors to conduct environmental impact analysis. Meanwhile, there is an increase in the principle of priority sector development due to the existence of priority sectors that have been determined by BCA in 2019. These priority sectors are in line with the government's priority sectors, namely the infrastructure sector.

BCA's coordination and collaboration principles have increased from year to year and fulfilled in 2019, indicating that BCA has coordinated and collaborated with stakeholders by conducting environmental to the public. In addition, the increase in this principle suggests an increase in participation in activities related to sustainable finance, which can be seen from the increase in the percentage of employees who have attended sustainable finance training. BCA has also fulfilled the principles of informative communication. The availability of a sustainability report indicates the implementation of the principle of informative communication and a RAKB submitted to stakeholders at a predetermined time.

The principles of responsible investment, the principles of good governance, and the principles of inclusion that are applied have also increased from year to year. The increase in the value of the responsible investment principle indicates that the bank has considered economic, social, and environmental factors and governance in its business decisions. Besides, the increase in the value of governance principles indicates that the bank has implemented good governance principles in terms of sustainable finance, including the existence of standard procedures on sustainable finance; the presence of a particular work unit in the implementation of sustainable finance; and the high remuneration of permanent employees against the regional minimum wage.

The increase in value also appears in the principle of inclusion, which can be seen from the increase in branch offices outside Java from year to year, so that the benefits of products and/or services provided by banks can be felt equally. Also, 
the number of digital banking services has increased. Furthermore, the bank's number of complaints has also increased, which indicates that the bank has a high commitment to serving every community.

In contrast to other principles, sustainable business strategy and practices principle has decreased from 2018 to 2019. The decrement is partly due to an increase in electricity and water usage, specifically an increase of $22.48 \%$ water use in 2019 compared to 2018. Besides, there was also a decrease in the allocation of funds related to the environment than the total funds spent on corporate social responsibility activities, the previous allocation of $1.06 \%$ in 2018 ; decreased to $0.56 \%$ in 2019.

Table 7. Sustainable Financial Index Composition Based on Principles - BNI

\begin{tabular}{|c|c|c|c|c|}
\hline BNI & 2016 & 2017 & 2018 & 2019 \\
\hline The principle of responsible investment & 0.0408 & 0.0549 & 0.0665 & 0.0694 \\
\hline $\begin{array}{l}\text { The principle of sustainable business } \\
\text { strategy and practices }\end{array}$ & 0.0179 & 0.0477 & 0.0536 & 0.0523 \\
\hline $\begin{array}{l}\text { The principles of social and environmental } \\
\text { risk management }\end{array}$ & 0.0000 & 0.0313 & 0.0313 & 0.0625 \\
\hline The principle of good governance & 0.0208 & 0.0314 & 0.0630 & 0.0598 \\
\hline $\begin{array}{l}\text { The principle of informative } \\
\text { communication }\end{array}$ & 0.0000 & 0.0000 & 0.0625 & 0.0625 \\
\hline The principle of inclusion & 0.0000 & 0.0326 & 0.1250 & 0.1115 \\
\hline $\begin{array}{l}\text { The principle of priority sector } \\
\text { development }\end{array}$ & 0.0000 & 0.0000 & 0.0000 & 0.0625 \\
\hline $\begin{array}{l}\text { The principle of coordination and } \\
\text { collaboration }\end{array}$ & 0.0083 & 0.0323 & 0.0489 & 0.1250 \\
\hline Sustainable Financial Index & 0.0879 & 0.2302 & 0.4508 & 0.6055 \\
\hline
\end{tabular}

Source: Author's calculation

Table 7 describes the composition of the Sustainable Financial Index based on sustainable finance principles for BNI. Like Bank Mandiri and BCA, the principles of sustainable finance have been implemented in BNI since 2016. The principles that have been applied at BNI are from the principles of responsible investment, the principle of sustainable business strategy and practices, the principles of good governance, and the principles of coordination and collaboration. Overall, this principle has increased from year to year. The increase in the principle of responsible investment is due to the high percentage of credit lent to sustainable business compared to total bank credit, which was $41.2 \%$ in 2019 . This principle's increment is due to the bank can maintain $2.20 \%$ NPL for sustainable businesses in 2019. Besides, bank financial ratios are also at a healthy level. 
The principles of sustainable business strategy and practices have also increased from year to year. The increment is due to the decrease in water and paper usage, the increase in the allocation of funds provided by banks related to the environment, and the budget allocation for human resource development related to sustainable finance implementation. However, the change in the value of sustainable business strategies and practices from 2018 to 2019 is not significant since there is also an increment in electricity usage from 2018 to 2019 by $41.65 \%$ and the increment in fuel usage from 2018 to 2019 by $18.4 \%$.

Improvements in the principles of governance at BNI show that BNI has good governance in running its business, by the availability of standard operating procedures that govern the implementation of sustainable finance and an equal number of male and female workers. Furthermore, BNI's coordination and collaboration principles have increased from year to year. They reached the maximum value in 2019 due to the increasing number of competencies development related to sustainable finance, the increasing number of employees participating in competency development, and the increasing socialization to the public regarding the environment.

The principles of social and environmental risk management, the principles of informative communication, the principles of inclusion, and the principles of priority sector development have increased significantly from 2016 to 2019 . The increase in social and environmental risk management principles indicates that the bank has implemented the prudential principle by identifying, measuring, mitigating, supervising, and monitoring sustainable business. Bank also requires its prospective debtors to have an environmental impact analysis.

The principles of informative communication and the principles of inclusion that are applied can be seen from the availability of a Sustainability Report and the RAKB. The bank has also made efforts to ensure that the bank's products and/or services are accessible to all people by increasing branch offices outside Java from year to year. People outside Java can have benefit from the products and/or services provided by the bank. Besides, there is an increase in the number of digital banking services and increased public complaints that have been handled. In 2019 , $\mathrm{BNI}$ chose the renewable energy sector as a priority sector. The selection of these sectors is in line with the government's priority sectors so that banks can implement the principles of priority sector development.

Table 8. Sustainable Financial Index Composition Based on Principles - BRI

\begin{tabular}{lcccc}
\hline BRI & $\mathbf{2 0 1 6}$ & $\mathbf{2 0 1 7}$ & $\mathbf{2 0 1 8}$ & $\mathbf{2 0 1 9}$ \\
\hline The principle of responsible investment & 0.0729 & 0.0602 & 0.0532 & 0.0463 \\
$\begin{array}{l}\text { The principle of sustainable business } \\
\text { strategy and practices }\end{array}$ & 0.0179 & 0.0205 & 0.0294 & 0.0152 \\
\hline
\end{tabular}




\begin{tabular}{|c|c|c|c|c|}
\hline $\begin{array}{l}\text { The principles of social and } \\
\text { environmental risk management }\end{array}$ & 0.0000 & 0.0000 & 0.0000 & 0.0625 \\
\hline The principle of good governance & 0.0565 & 0.0572 & 0.0848 & 0.0541 \\
\hline $\begin{array}{l}\text { The principle of informative } \\
\text { communication }\end{array}$ & 0.0000 & 0.0000 & 0.0625 & 0.0625 \\
\hline The principle of inclusion & 0.0417 & 0.0147 & 0.0346 & 0.1138 \\
\hline $\begin{array}{l}\text { The principle of priority sector } \\
\text { development }\end{array}$ & 0.0000 & 0.0000 & 0.0000 & 0.0625 \\
\hline $\begin{array}{l}\text { The principle of coordination and } \\
\text { collaboration }\end{array}$ & 0.0000 & 0.0000 & 0.0833 & 0.0000 \\
\hline Sustainable Financial Index & 0.1889 & 0.1527 & 0.3478 & 0.4168 \\
\hline
\end{tabular}

Source: Author's calculation

Like the other banks above, BRI had also implemented several sustainable finance principles in 2016, and sustainable finance principles are being applied more in the next year. The principles of social and environmental risk management, the principle of informative communication, and the principle of priority sector development are the principles that have been successfully implemented by BRI up to 2019. By applying social and environmental risk management principles, BRI has implemented the principle of prudence in implementing business by requiring prospective debtors to analyze environmental impacts. BRI has also identified, measured, mitigated, supervised, and monitored its sustainable businesses. BRI also has programs to manage social and environmental risks.

The principle of informative communication can be seen from the existence of a sustainability report available to the public and by the existence of a RAKB submitted on time. Meanwhile, BRI has implemented the principle of priority sector development to develop priority economic sectors, including energy, agriculture, manufacturing, infrastructure, and micro, small and medium enterprises.

The inclusive principle implemented by BRI has increased from year to year. Similar to its application to other banks, the increase in this principle indicates that the bank has made efforts to ensure the availability of products and/or services and ensure that these products and/or services are accessible to all people by increasing the number of branch offices outside Java, increasing the number of banking services, and increasing the number of complaints handled.

On the other hand, several principles experienced a decline in value in 2019 compared to previous years. These principles are the principles of responsible investment, sustainable business strategy and practices, and governance principles. The decline in the principle of responsible investment was due to an increase in non-performing earning assets, an increase in the level of non-performing loans, a decrease in return on equity, and a decrease in net interest margin. However, BRI still applies this principle, which can be seen from the high percentage of loans 
extended to sustainable businesses, $57.3 \%$ of total bank loans. Besides, BRI also has products that meet the criteria for sustainable business activities.

The decline in the principles of sustainable business strategies and practices was partly due to the increase in electricity and fuel usage in 2019 compared to the previous year. Also, there was a decrease in the percentage of fund allocation related to the environment. The absence of budget allocation for human resource development related to the implementation of sustainable finance and the lack of information on water use in BRI has resulted in the low value of the principles of sustainable business strategies and practices.

The principles of coordination and collaboration were only seen to have been implemented in 2018. In that year, BRI employees had participated in competency development related to sustainable finance. Meanwhile, there was no information on the number of competency developments for employees or information on socialization made to the public regarding the environment in other years. The lack of information causes a low value on this principle.

Table 9. Sustainable Financial Index Composition Based on Principles Bank CIMB

\begin{tabular}{lcccc}
\hline Bank CIMB & $\mathbf{2 0 1 6}$ & $\mathbf{2 0 1 7}$ & $\mathbf{2 0 1 8}$ & $\mathbf{2 0 1 9}$ \\
\hline $\begin{array}{l}\text { The principle of responsible investment } \\
\begin{array}{l}\text { The principle of sustainable business } \\
\text { strategy and practices }\end{array}\end{array}$ & 0.0333 & 0.0398 & 0.0513 & 0.0802 \\
$\begin{array}{l}\text { The principles of social and } \\
\text { environmental risk management }\end{array}$ & 0.0000 & 0.0000 & 0.0313 & 0.0625 \\
$\begin{array}{l}\text { The principle of good governance } \\
\begin{array}{l}\text { The principle of informative } \\
\text { communication }\end{array}\end{array}$ & 0.0354 & 0.0388 & 0.0426 & 0.1024 \\
$\begin{array}{l}\text { The principle of inclusion } \\
\begin{array}{l}\text { The principle of priority sector } \\
\text { development }\end{array}\end{array}$ & 0.0000 & 0.0000 & 0.0625 & 0.0625 \\
$\begin{array}{l}\text { The principle of coordination and } \\
\text { collaboration }\end{array}$ & 0.0000 & 0.0000 & 0.0521 & 0.0862 \\
\hline Sustainable Financial Index & 0.0000 & 0.0000 & 0.0164 & 0.0833 \\
\hline
\end{tabular}

Source: Author's calculation

Bank CIMB has also implemented sustainable finance principles since 2016, as shown in Table 9. The principles of responsible investment, the principle of sustainable business strategy and practices, and governance principles that have been implemented since 2016 have increased from year to year. The increase in 
the value of the responsible investment principle indicates that the bank has considered economic, social, and environmental factors in its business decisions. The implementation of the responsible investment principle can be seen from the maintained financial ratios and the credit that has been given to sustainable businesses in 2019. Besides, the increase in the value of governance principles indicates that the bank has implemented the principles of good governance in terms of sustainable finance by the existence of standard procedures regarding sustainable finance; a particular work unit in the implementation of sustainable finance; and the high remuneration of permanent employees against the regional minimum wage.

The principles of sustainable business strategy and practices have increased from 2019 compared to 2016. However, compared to 2018, the increase in value for this principle is not significant. Besides, the principle of sustainable business strategy and practices is the lowest value than other principles, due to the absence of information provided by Bank CIMB in the sustainability report regarding the indicators used, including changes in the use of water, electricity, paper, and fuel; as well as the absence of information regarding budget allocation for resource development related to the implementation of sustainable finance.

The principles of social and environmental risk management, the principles of informative communication, the principles of inclusion, the principles of priority sector development, and the principles of coordination and collaboration are the principles that have increased from 2016 to 2019. The increasing value of social and environmental risk management principles is marked by an explanation regarding the identification, measurement, mitigation, and monitoring of the sustainable business it is running. Besides, the increase in this principle is also due to potential debtors' obligation to provide an analysis of environmental impacts. Furthermore, CIMB Bank also has programs to manage social and environmental risks.

Bank CIMB has also implemented the principles of informative communication in its business practices, including by providing sustainability reports on time to the public and submitting the RAKB. Bank CIMB has also made efforts to make its products and/or services accessible to all people without exception, which is marked by the increase in the number of branch offices outside Java, the availability of digital banking services for the public, and the increasing number of complaints that have been handled by Bank CIMB. Bank CIMB has also implemented the principle of developing priority leading sectors by setting priority sectors for financing to be provided, including the oil palm plantation sector, the infrastructure sector, and the micro, small, and medium enterprises sector. 


\section{CONCLUSION}

Based on the obtained results, it can be seen that overall, Sustainable Financial Index in each bank has increased significantly from year to year. The increase in Sustainable Financial Index could be caused by several things, including the increased awareness of banks to implement sustainable finance in their business processes and advanced knowledge of sustainable finance. The increase in IKB can be related to the implementation of POJK 51 regulations that require banks to implement sustainable finance programs, of which BUKU 4 is mandatory starting in 2019.

The results also show that banks have implemented several sustainable finance principles since 2016, and each year the principles of sustainable finance are being applied more until finally, the eight principles had been implemented in every bank in 2019. The implementation of these principles indicates that the banks in this study have implemented sustainable finance practices, as stipulated in POJK 51. Meanwhile, each bank has different characteristics, so that in practice, the principles that stand out in the implementation of sustainable finance differ from one bank to another.

However, the index built has several limitations. Limitations include the number of indicators used and their suitability with the principles used. Given these limitations, further index development is highly recommended.

\section{REFERENCE}

Bisogno, M., Cuadrado-Ballesteros, B. and García-Sánchez, I.M., 2017. Financial sustainability in local governments: Definition, measurement and determinants. In: Financial Sustainability in Public Administration: Exploring the Concept of Financial Health.

Lee, Y.J. and Huang, C.M., 2007. Sustainability index for Taipei. Environmental Impact Assessment Review.

Otoritas Jasa Keuangan, 2014. Roadmap Keuangan Berkelanjutan di Indonesia, 2015-2019. Otoritas Jasa Keuangan.

Otoritas Jasa Keuangan, 2017. Peraturan Otoritas Jasa Keuangan Nomor 51/POJK. 03/2017 tentang Penerapan Keuangan Berkelanjutan bagi Lembaga Jasa Keuangan, Emiten, dan Perusahaan Publik.

Otoritas Jasa Keuangan, 2018. Pedoman Teknis Bagi Bank Terkait Implementasi POJK Nomor 51/POJK.03/2017 Tentang Penerapan Keuangan Berkelanjutan Bagi Lembaga Jasa Keuangan (LJK), Emiten, dan Perusahaan Publik. 
Pati, A.P., 2008. Subsidised micro financing and financial sustainability of SHGs. The Indian Journal of Commerce, 61(4).

Piot-Lepetit, I. and Nzongang, J., 2014. Financial sustainability and poverty outreach within a network of village banks in Cameroon: A multi-DEA approach. European Journal of Operational Research. 